\title{
Pemahaman Sistem dan Dinamika Demokrasi Pancasila dengan Sikap Demokrasi dan Tanggung Jawab Belajar
}

\author{
Kaharudin $^{1 *}$, Mohamad Abduh $^{2}$, Suidat $^{2}$ \\ ${ }^{I}$ SMA Negeri 78 Jakarta, Indonesia \\ ${ }^{2}$ STKIP Arrahmaniyah, Indonesia
}

\begin{abstract}
Abstrak - Penelitian ini bertujuan untuk memperoleh data empiris mengenai: pemahaman system dan dinamika demokrasi Pancasila dengan sikap demokrasi dan tanggung jawab belajar siswa. Penelitian dilaksanakan mulai Agustus sd Oktober 2020, metode yang digunakan adalah survey dengan pendekatan korelasional. Populasi penelitian adalah siswa SMAN 78 Jakarta 199 siswa. Teknik analisis data menggunakan analisis regresi berganda. Instrumen yang digunakan adalah tes untuk variabel $\mathrm{X}_{1}$ (pemahaman sistem dan dinamika demokrasi pancasila), sedangkan variabel $\mathrm{X}_{2}$ (sikap demokrasi siswa), dan variabel $\mathrm{Y}$ (tanggung jawab belajar siswa) menggunakan angket. Keseluruhan instrument diuji coba tingkat validitas dan reliabilitasnya pada taraf signifikansi 0,95 atau $0,05 \%$. Pengujian hipotesis dilakukan dengan korelasi Product Moment. Dari hasil perhitungan diperoleh $r_{\mathrm{xy}} \mathrm{X}_{1}$ dan $\mathrm{X}_{2}$ bersama-sama dengan $\mathrm{Y}$ sebesar 0,9851 adapun rtabel sebesar 0,1391. Karena rhitung lebih besar dari rtabel $(0,9851>0,1391)$, maka dapat disimpulkan bahwa terdapat hubungan signifikan. Koefisien determinasi sebesar 97,05 . Dengan demikian konstribusi variabel $X_{1}$ dan $X_{2}$ terhadap $\mathrm{Y}$ sebesar $97,05 \%$. Tingkat keberartian hubungan kedua variabel dilakukan dengan uji- $F$. Dari hasil perhitungan doperoleh $F_{\text {hitung }}$ sebesar 3226,158 Taraf signifikansi 0,05 dengan $d k=199$ dan $F_{\text {tabel }}$ sebesar 3,042 Dengan demikian $F_{\text {hitung }}$ lebih besar dari $F_{\text {tabel }}$ $(3226,158>3,042)$. Perbandingan kedua nilai $t_{\text {hitung }}$ tersebut menunjukkan adanya pengaruh yang berarti.
\end{abstract}

\author{
Kata kunci: \\ Dinamika Demokrasi, \\ Sikap Demokrasi, \\ Tanggung Jawab Belajar.
}

\section{Histori:}

Dikirim: 10 Maret 2021

Direvisi: 15 Maret 2021

Diterima: 17 Maret 2021

Online: 18 Maret 2021

\section{Identitas Artikel:}

Kaharudin, K., Abduh, M., \& Suidat, S. (2021). Pemahaman Sistem dan Dinamika Demokrasi Pancasila dengan Sikap Demokrasi dan Tanggung Jawab Belajar. Jurnal Citizenship Virtues, $1(1), 57-62$.

\section{PENDAHULUAN}

Sejalan dengan zaman, dewasa ini, nyaris seluruh warga di dunia mengakui menjadi pengikut paham demokrasi. Indonesia salah satunya yang merupakan negara tumbuh yang berusaha untuk membentuk teknik prosedur politik demokrasi sejak memproklamasikan kemerdekaan pada tahun 1945. Para penggagas bangsa berkeinginan agar terciptanya pemerintahan yang mempertahankan bangsa

*Corresponding author

E-mail: kaharuddinshuba@gmail.com 
Indonesia dan segenap tumpah darah Indonesia, meningkatkan ketenteraman umum, mencerdaskan kehidupan bangsa dan ikut serta melakukan ketertiban dunia yang berdasarkan kemerdekaan, perdamaian yang kekal dan keadilan sosial. Semua itu menggambarkan ide dasar yang melandasi kehidupan negara yang demokratis. Landasan tentang commit to user demokrasi telah tercantum dalam Pembukaan UUD 1945 maupun Batang Tubuh UUD 1945 adalah sebagai bentuk keseriusan negara Indonesia. Dimana semua pernyataan dalam UUD 1945 didasari oleh nyawa dan semangat demokrasi. Dalam penyusunan naskah UUD 1945, ini di lakukan secara demokratis yang mana merangkum semua golongan dan kepentingan yang ada dalam masyarakat dengan cara demokratis, yang mana konsep inilah yang tidak dapat di pisahkan.

Ditegaskan pula pada Undang-Undang Republik Indonesia Nomor 23 Tahun 2003 tentang sistem pendidikan nasional disamping memuat tujuan pendidikan nasional, juga mengembangkan kemampuan akademik peserta didik dan menuntut dikembangkannya kompetensi moral, sosial serta keterampilan. Dengan menyadari hal tersebut di atas, maka haruslah memperhatikan faktor yang memperkuat tujuan pendidikan salah satunya dengan menanamkan sikap kepada siswa. Sedangkan pada kenyataanya, kurang dibina dalam menumbuh kembangkan sikap yang dibutuhkan untuk menyukseskan tujuan pendidikan nasional salah satunya adalah tujuan pendidikan kewarganegaraan yaitu siswa yang mempunyai sikap demokrasi.

Terfokusnya kepada pengetahuan bukan kepada keterampilan dan sikap yang dikembangkan ini adalah faktor yang sangat mempengaruhi dalam tercapainya tujuan pendidikan. Hal ini terbukti bahwa pada pendidikan pada umumnya terfokus kepada pengetahuan anak terhadap materi yang diajarkan tidak kepada sikap yang ditampikan oleh anak tersebut. Maka dengan itu, dalam rangka meningkatkan tujuan pendidikan salah satunya yaitu menjadi warga negara yang demokratis dan bertanggung jawab belajar siswa, khususnya pada mata pelajaran PPKn, dipandang perlu untuk meningkatkan sikap demokrasi siswa. Hal ini karena pada dasarnya tujuan pendidikan kewarganegaraan menjadikan warga negara Indonesia yang terdas, bermartabat, dan aktif dalam kehidupan berbangsa dan bernegara (Ubaedillah \& Rozak, 2012).

Meningkatkan sikap demokrasi siswa salah satu caranya adalah dengan menumbuhkembangkan warga negara yang demokratis, ini semua tidak akan berhasil apabila seorang guru tidak berusaha menanamkan sikap demokrasi kepada ada itu sendiri pada kehidupan nyata. Tujuan selanjutnya selain dari menanamamkan sikap demokrasi, yaitu menanamkan Tanggung Jawab Belajar Siswa yang kurang diperhatikan oleh kalangan pendidik khususnya, umumnya oleh dunia pendidikan. Dimana sikap ini akan lengkap apabila dibarengi dengan Tanggung Jawab Belajar Siswa itu sendiri. Dengan menanamkan kedua sikap ini diharapkan tujuan pendidikan khususnya pada mata pelajaran PPKn ini terlaksana. Sesuai dengan sistem dan dinamika demokrasi Pancasila yang diterapkan di Indonesia yang mengacu kepada prinsip-prinsip demokrasi Indonesia yang sesuai dengan nilai-nilai Pancasila sebagai falsafah hidup dan ideologi negara ini, sehingga pelaksanaan demokrasi di Indonesia sejalan dengan Pancasila tertutama sila keempat yakni, Kerakyatan yang dipimpin oleh hikmat kebijaksanaan dalam permusyawaratan/ perwakilan. Sila tersebut menyiratkan bahwa pelaksanaan demokrasi harus mengedepankan musyawarah untuk mencapai hasil yang mufakat. 
Persoalan yang sering dialami oleh sebagian besar orang adalah upaya belajar tidak membuat mereka mampu menanamkan sikap yang mereka pelajari. Padahal, dalam kontek belajar, kondisi tersebut sesungguhnya tidak boleh terjadi. Setiap proses belajar seharusnya mampu mengantarkan seorang pembelajar dari kondisi tidak memiliki menjadi memiliki, dari tidak bermakna menjadi bermakna, yang selanjutnya memungkinkan mereka untuk mengaktualisasikan diri mereka dalam hidup dan kehidupan. Hal ini terbukti bahwa selalu kurang membahagiakan berbagai pihak yang berkepentingan stakholder ini semua setidaknya disebabkan oleh tiga hal pertama ada sekarang (need assessment) yaitu dari hasil pengajaran dan pembelajaran berbagai bidang ilmu. Kedua, teknik, strategi, dan metodologi yang kurang sesuai dengan materi. Ketiga, prasarana yang mendukung proses pembelajaran (Shoimin, 2014: 16). Pudjiastuti (2020a) menjelaskan implementasi nilai-nilai Pancasila bagi generasi milenial yang terintegrasi dalam kurikulum pendidikan dengan menekankan aspek praktek, tidak kognitif semata, mengikutsertakan semua stakeholder yang ada. Mengenalkan kearifan local mulai dari cerita rakyat, kesenian tradisional, hingga permainan tradisional.

Menumbuh-kembangkan sikap siswa sesuai dengan materi yang diajarkan, dimana dengan pemahaman materi sistem dan dinamika demokrasi pancasila siswa diharuskan untuk mempunyai sikap demokrasi sekaligus melatih dan mengembangkan Tanggung Jawab Belajar Siswa dalam kegiatan pembelajaran. Dengan memperdalam sistem dan dinamika demokrasi Pancasila tersebut siswa secara sadar menumbuh kembangkan sikap demokrasi siswa itu sendiri dan sekaligus dilatih untuk menanamkan sikap tannggung jawab dalam segala bidang kehidupan, hal ini karena bukan hanya sekedar mengembangkan pengetahuan saja namun akan memberi kesadaran kepada siswa bahwa betapa pentinya sikap demokrasi ditanamkan di kehidapan sehari-hari, yang mana akan menanamkan pula sikap tanggung jawa siswa itu sendiri.

Hasil penelitian terdahulu, Septiliana (2011) mengkaji hubungan antara pemahaman demokrasi dan Budaya demokrasi dengan sikap demokrasi pada siswa kelas XI Sekolah Menengah Atas Negeri 2 Karanganyar Tahun Ajaran 2010/2011 menemukan bahwa terdapat hubungan yang signifikan antara pemahaman demokrasi dengan sikap demokrasi. Adapun Aini (2015) menjelaskan dalam risetnya bahwa Tanggung Jawab Belajar Siswa merupakan salah satu sikap sosial yang harus ditanamkan kepada siswa sesuai dengan tujuan pendidikan yang tidak hanya mempelajari ilmu pengetahuan saja, tetapi juga membangun karakter. Dari kedua riset tersebut membuktikan bahwa sikap demokrasi dan Tanggung Jawab Belajar Siswa sangatlah penting ditanamkan disemua bidang ilmu pendidikan. Bukan saja di mata pelajaran PPKn saja. Selanjutnya Pudjiastuti (2020b) menjelaskan bahwa cara yang dapat dilakukan untuk menginternalisasikan nilainilai luhur Pancasila adalah; memperkuat sistem pendidikan, meningkatkan identitas diri dan karakter bangsa, pemimpin nasional memiliki komitmen yang tinggi, mengimplementasikan nilai-nilai Pancasila dalam kehidupan nyata agar memiliki kemampuan untuk mengangkal pengaruh negatif.

Hal ini sejalan dengan kondisi di SMAN 78 Jakarta, dimana pada kenyataannya pemahaman materi sistem dan dinamika demokrasi pancasila dalam pembelajaran di kelas belum menyentuh kepada rana sikap siswa, hanya kepada rana pemahaman saja yaitu pemahaman materi sistem dan dinamika demokrasi pancasila, apalagi untuk meningkatkan sikap siswa khususnya Tanggung Jawab Belajar Siswa dan 
sikap demokrasi siswa. Kondisi demikian di perparah dengan kemampuan penyampaian materi oleh guru yang tidak menarik siswa untuk belajar, oleh karena kondisi demikian, perlu dilakukan penelitian di SMAN 78 Jakarta dengan pemahaman materi sistem dan dinamika demokrasi pancasila dalam meningkatkan sikap demorasi siswa dan Tanggung Jawab Belajar Siswa pada mata pelajaraan Pendidikan Pancasila dan Kewarganegaraan kelas XI (Sebelas) semester ganjil. Pemahaman materi sistem dan dinamika demokrasi pancasila dalam pembelajaran di kelas diharapkan akan menumbuhkan sikap demokrasi siswa, selain itu juga merangsang siswa untuk mempunyai Tanggung Jawab Belajar Siswa dalam belajar sekaligus melatih dan mengembangkan kesadaran siswa betapa pentinya mempunyai sikap demokrasi dan Tanggung Jawab Belajar Siswa pada kehidupan sehari-hari.

\section{METODE PENELITIAN}

Dalam penelitian ini peneliti memakai metode survey dengan pendekatan korelasional (Sugiono, 2017). Populasi penelitiannya adalah siswa kelas XI SMAN 78 Jakarta, Palmerah, terdiri dari 199 siswa. Pelaksanaan penelitian ini dilakukan pada bulan Agustus sampai Oktober, semester ganjll tahun pelajaran 2020/2021. Instrumen yang dipakai untuk mengukur variabel sikap demokrasi siswa dan tanggung jawab belajar siswa keduanya menggunakan angket skala sikap, sedangkan variabel Pemahaman materi sistem dan dinamika demokrasi pancasila meggunakan instrumen berupa tes pilian ganda. Keseluruhan instrument telah diuji coba tingkat validitas dan reliabilitasnya pada taraf signifikansi 0,95 atau 0,05\%. Ujian hipotesis dilakukan dengan korelasi Product Moment (Pudjiastuti, 2019).

\section{HASIL DAN PEMBAHASAN}

\section{Pengujian Siginifikasi Parsial antara Pemahaman Materi Sistem dan Dinamika Demokrasi Pancasila $\left(\mathrm{X}_{1}\right)$ dengan Tanggung jawab belajar siswa $(\mathbf{Y})$}

Uji hipotesis penelitian yang mengkaji hubungan signifikan antara pemahaman materi sistem dan dinamika demokrasi pancasila dengan tanggung jawab belajar siswa dilakukan dengan analisis korelasi. Hasil analisis untuk mengetahui korelasi hubungan signifikan antara antara pemahaman materi sistem dan dinamika demokrasi pancasila dengan tanggung jawab belajar siswa, maka diperoleh $r_{\text {hitung }}$ sebesar 0,9827. Hasil tersebut kemudian dikonsultasikan dengan $r_{\text {tabel }}$ sebesar $0,1391(\alpha=0,05$ dan $\mathrm{N}=199)$. Hasil konsultasi tersebut menunjukan bahwa $r_{\text {hitung }}=0,9827 \geq 0,1391=r_{\text {tabel }}$,

\section{Pengujian Siginifikasi Parsial antara Sikap Demokrasi Siswa $\left(\mathbf{X}_{2}\right)$ dengan Tanggung jawab belajar siswa (Y)}

Uji hipotesis penelitian yang mengkaji hubungan signifikan antara sikap demokrasi siswa dengan tanggung jawab belajar siswa dilakukan dengan analisis korelasi. Hasil analisis untuk mengetahui korelasi hubungan signifikan antara antara sikap demokrasi siswa dengan tanggung jawab belajar siswa, maka diperoleh $r_{\text {hitung }}$ sebesar 0,9746. Hasil tersebut kemudian dikonsultasikan dengan $r_{\text {tabel }}$ sebesar $0,1391(\alpha=0,05$ dan $\mathrm{N}=199)$. Hasil konsultasi tersebut menunjukan bahwa $r_{\text {hitung }}=0,9746 \geq 0,1391=r_{\text {tabel }}$. 
Perhitungan Koefisien Korelasi antara Pemahaman Materi Sistem dan Dinamika Demokrasi Pancasila $\left(X_{1}\right)$ dan Sikap Demokrasi Siswa $\left(X_{2}\right)$ dengan Tanggung jawab belajar siswa $(\mathbf{Y})$

Uji hipotesis penelitian yang mengkaji hubungan signifikan antara pemahaman materi sistem dan dinamika demokrasi pancasila dan sikap demokrasi siswa dengan tanggung jawab belajar siswa dilakukan dengan analisis korelasi ganda. Hasil analisis untuk mengetahui korelasi hubungan signifikan antara pemahaman materi sistem dan dinamika demokrasi pancasila dan sikap demokrasi siswa dengan

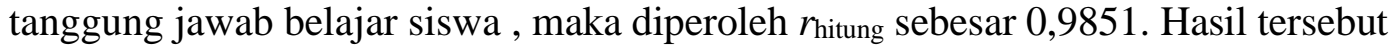
kemudian dikonsultasikan dengan $r_{\text {tabel }}$ sebesar 0,1391 ( $\alpha=0,05$ dan $\left.\mathrm{N}=199\right)$. Hasil konsultasi tersebut menunjukan bahwa $r_{\text {hitung }}=0,9851 \geq 0,1391=r_{\text {tabel }}$.

\section{KESIMPULAN}

Dari hasil pengisian tes pemahaman materi sistem dan dinamika demokrasi pancasila menunjukkan bawah keberhasilan pemahaman materi sistem dan dinamika demokrasi pancasila pada tanggung jawab belajar siswa atas 3,44\% ditentukan oleh aspek lain di luar. Bisa dikatakan ber tanggung jawab belajar siswa pada materi sistem dan dinamika demokrasi pancasila lebih dari $1 / 2$ (setengah) yang bisa dinyatakan memiliki hubungan antara pemahaman materi sistem dan dinamika demokrasi pancasila dengan tanggung jawab belajar siswa. Dan dari hasil pengisian kuesioner sikap demokrasi siswa menunjukkan bahwa sikap demokrasi siswa pada tanggung jawab belajar siswa sebesar 5,02\% ditentukan oleh aspek lain di luar. Bisa dikatakan sikap demokrasi siswa pada tanggung jawab belajar siswa lebih dari $1 / 2$ (setengah) yang bisa dinyatakan memiliki hubungan antara sikap demokrasi siswa dengan tanggung jawab belajar siswa. Dari hasil kedua tersebut membuktikan bahwa ada korelasi hubungan signifikan antara pemahaman materi sistem dan dinamika demokrasi pancasila dan sikap demokrasi siswa secara bersama-sama memhubungani dengan tanggung jawab belajar siswa dilakukan dengan analisis korelasi ganda, dengan hasil diperoleh $r_{\text {hitung }}=0,9851$. Hasil tersebut kemudian dikonsultasikan dengan $r_{\text {tabel }}=0,1391(\alpha=0,05$ dan $\mathrm{N}=199)$. Hasil konsultasi tersebut menunjukan bahwa $r_{\text {hitung }}=0,9851 \geq 0,1391=r_{\text {tabel }}$. Hal ini menunjukan bahwa ada hubungan yang signifikan antara pemahaman materi sistem dan dinamika demokrasi pancasila dan sikap demokrasi siswa secara bersama-sama memhubungani dengan tanggung jawab belajar siswa, pada 199 siswa di SMAN 78 Jakarta. Dari perhitungan koefisien determinan (KD) diketahui bahwa hubungan sikap demokrasi siswa dan tanggung jawab belajar siswa secara bersama-sama dengan pemahaman materi sistem dan dinamika demokrasi pancasila adalah sebesar $97,05 \%$ sedangkan 2,95\% ditentukan oleh faktor lain.

\section{REFERENSI}

Aini, S. N. (2015). Penerapan sikap sosial tanggungjawab pada mata pelajaran IPS Terpadu kelas VII di MTsN Tumpang Kabupaten Malang (Skripsi, Universitas Islam Negeri Maulana Malik Ibrahim). 
Septiliana, N. R. (2011). Hubungan antara pemahaman demokrasi dan budaya demokrasi dengan sikap demokrasi pada siswa kelas XI sekolah menengah atas negeri 2 Karanganyar tahun ajaran 2010/2011 (Skripsi, Universitas Sebelas Maret).

Shoimin, A. (2014). Model Pembelajaran Inovatif dalam Kurikulum 2013. Yogyakarta: Ar-ruzz media.

Sugiono. (2017). Metode Penelitian Kuantitatif, Kualitatif dan R\&D, Bandung: Alfabeta.

Ubaedillah, A., \& Rozak, A. (2012). Pendidikan Kewarganegaraan (Civic Education): Pancasila, Demokrasi, HAM, dan Masyarakat Madani. Jakarta: ICCE UIN Syarif Hidayatullah.

Pudjiastuti, S. R. (2019). Penelitian Pendidikan. Yogyakarta: Media Akademi.

Pudjiastuti, S. R. (2020a). Implementasi Nilai-Nilai Pancasila bagi Generasi Milenial. In Tim Asosiasi Dosen Pancasila dan Kewarganegaraan (Eds.). Implementasi Nilai-Nila Pancasila Di Era 4.0, pp. 65-88. Depok: Gemala.

Pudjiastuti, S. R. (2020b). Internalisasi Nilai-Nilai Pancasila Dalam Mencegah Paham Radikal. Jurnal Ilmiah Mimbar Demokrasi, 19(2), 32-39. 